\title{
The Influence of School Culture, Teacher Performance, Principal Leadership on Quality of Education in High Schools in Ende Regency
}

\author{
Hilwantris Wasa Weto ${ }^{1}$, Rudi Wahyono ${ }^{2}$, Fajar Supanto ${ }^{2}$ \\ ${ }^{1}$ Scholar in Master in Management Program, University of Merdeka Malang, Indonesia \\ ${ }^{2}$ Lecturer at the Faculty of Economics and Business, University of Merdeka Malang, Indonesia
}

\begin{abstract}
This study aims to describe school culture, teacher performance, principal leadership and quality of education in senior high schools in Ende district, to examine school culture, teacher performance, and principal leadership, simultaneously affecting the quality of education in senior secondary schools in Ende district. examining school culture, teacher performance, and principal leadership partially affect the quality of education at high schools in Ende Regency, knowing the school culture variables, teacher performance, principal leadership, which have a dominant effect on the quality of education in senior high schools in Ende Regency. This type of research uses quantitative analysis with the method used is the quantitative description. The number of samples in this study were 72 respondents using the purposive sampling method. The data analysis technique used is multiple linear regression analysis. The results of the analysis show that school culture, teacher performance, and principal leadership simultaneously have a significant effect on the quality of education in senior secondary schools in Ende district. Partially school culture does not have a significant effect on the quality of education in senior secondary schools in Ende district. Teacher performance and principal leadership partially have a significant effect on the quality of education in secondary schools in the Ende district.
\end{abstract}

Keywords: School Culture, Teacher Performance, Principal Leadership, Education Quality.

\section{INTRODUCTION}

Education is essentially one of the basic human needs in order to improve the quality of human resources in order to achieve a more advanced and prosperous life level. Law Number 20 of 2003 Article 1 paragraph 1 concerning the National Education System mandates that education is a conscious and planned effort to create an atmosphere of learning and the learning process so that students actively develop their potential to have religious spiritual strength, self-control, personality, intelligence. , noble character and skills possessed by himself, society, nation and state [1].

One of the most serious problems in education in the country today is the low quality of education in various types and levels of education. Many argue that the low quality of education is one of the factors that hinders the provision of human resources with expertise and skills to meet the demands of national development in various fields. The quality of education as one of the pillars of human resource development (HR) has a strategic meaning for national development .

However, the education system in Indonesia is very low, with the quality of education getting lower. The low quality of education is influenced by several factors including; effectiveness, efficiency, relevance, and standardization of education, inadequate educational facilities and infrastructure, low student achievement, and low quality of teachers (Prinansa in Madjid) [2].

The quality of education will be of high quality if it is supported by an adequate education component. These components become input (input) to the process so as to produce superior outputs and outcomes. According to Triana education quality is the satisfaction of education service recipients with education services. In the context of education, the definition of quality refers to the input, process, output, and impact [3].

According to Sukmadinata school culture is a pattern of values, principles, traditions and habits that are formed in the long course of school, developed by the school for a long time and become a reference and are believed by all school members, as a result [4]. school trips, as well as being the product of the interaction of various forces that enter the school. The dynamic condition of the school is a combination of all school members who have different social backgrounds and interact with each other continuously, thus forming a cultured value system and belonging together at school. 
According to Suharsaputra "teacher performance is basically a teacher's activity in carrying out their duties and obligations as a teacher and educator in schools that can describe their work performance in carrying out all of that" [5]. Based on this opinion, teacher performance is an important factor in efforts to improve the quality of education, especially improving the quality of learning in schools.

Educators are an element of education. The success of educators in making quality education can be found through their work. Low teacher quality is certainly caused by differences in the quality of performance, competence, and will affect teacher performance (Madjid) [2]. Thus, the performance of educators needs to be improved so that the quality of education can be improved.

The principal as the education leader is the person most responsible for the success of education in his school. According to (Rosyada), the leadership of the principal has a very large role [6]. He must be strong and have a strong leadership style to encourage all his teachers to work totally in educating his students, have a vision for school progress, be consistent with his vision, but still democratic and respect the views of the staff. Referring to the discussion of each of the indicators above, the researcher draws conclusions and sees that the three indicator variables are important aspects that can support the quality of education at high schools in Ende Regency, and become a place of research. These three schools are located in the Kota Ende area, in the Ende District.

The purpose of this study is as follows to describe the school culture, teacher performance, principal leadership and quality of education in high schools in Ende Regency, to simultaneously analyze the influence of school culture, teacher performance, principal leadership, on the quality of education in senior high schools in Indonesia. Ende District, to partially analyze the influence of school culture, teacher performance, principal leadership on the quality of education in high schools in Ende Regency, to determine the school culture variables, teacher performance, principal leadership, which have a dominant effect on the quality of education in secondary schools above in Ende Regency.

\section{LITERATURE REVIEW}

\subsection{Quality of Education}

In the context of education, the definition of quality includes inputs, processes, and outputs of education (Depdiknas) [7]. Educational input is anything that must be available because it is needed for the process to take place. The educational process is a change in something else by integrating school inputs so as to create a pleasant learning situation, motivation and high interest in learning. The output of education is school performance which can be measured from its quality, productivity, efficiency, innovation and work morale. According to Usman quality in education includes the quality of inputs, processes, outputs and outcomes [8]. Educational input is declared of high quality if it is ready to proceed. Quality education process if it is able to create a PAKEM atmosphere (Active, Creative, Effective and Fun Learning).

According to Sudradjad quality education is education that is able to produce graduates who have the ability or competence, both academic competence and vocational competence, which are based on personal and social competences, as well as noble moral values, which are all life skills [9]. According to Usman the quality of education includes input, process, output, outcomes [8]. Thus the indicators of the quality of education are as follows: Input, Process, Output, Outcomes.

\subsection{School Culture}

In everyday people's life, it cannot be separated from the cultural ties that are created. Culture differentiates people from one another in how they interact and act to complete a job. Culture binds members of community groups into a unified view that creates uniformity of behavior or action. According to Zamroni provides a limitation that school culture is a pattern of values, principles, traditions and habits that are formed in the long course of school, school culture is developed over a long period of time and becomes a reference and is believed by all citizens. schools so as to encourage positive attitudes and behavior of school residents [10].

According to Wahjosumidjo describing school culture is something that is built from the results of the meeting between the values adopted by the principal as a leader and the values shared by teachers and employees at the school [11]. According to Moerdiyono defines school culture as shared beliefs and values which become a strong bond of togetherness as citizens of a community[12]. According to this definition, a school can have a number of cultures with one dominant culture and a number of other cultures as subordination. The most important principle of school culture, namely the elements contained in the school culture that can be maintained in order to continuously improve quality,

According to Robbins, school culture is a special description of organizational culture that discusses values that grow and develop in a cultural school which is meant to include positive habits that can change the behavior of school members or students in a better direction [13]. Thus the indicators of school culture include: Innovation and risk taking, result orientation, team orientation towards work activities.. 


\subsection{Teacher Performance}

Teacher performance is basically the performance or performance carried out by teachers in carrying out their duties as educators, and the quality of teachers will greatly determine the quality of educational outcomes, because teachers are the party who has the most direct contact with students and the learning process in school education institutions. According to Herdi that teacher performance is the result of achievement by teachers after carrying out their duties as teaching staff, which is supported by their performance in carrying out their duties in the field properly in procuring tools or human resources that show the charismatic nature of the teacher as a teacher and educator [14].

Teacher performance is an achievement that can be achieved by a person or organization based on certain criteria and measurement tools. According to Samsudin, it provides an understanding of performance as the level of task implementation that a person can achieve by using existing abilities and boundaries that have been set to achieve optimal goals [15]. This understanding provides an understanding that performance is an act or behavior of someone that can be directly or indirectly observed by others.

Teacher performance is basically the performance or performance performed by teachers in carrying out their duties as educators. The quality of teacher performance will greatly determine the quality of educational outcomes, because teachers are the party who has the most direct contact with students in the educational process or learning in educational institutions. According to Yuliana, there are many factors that affect teacher performance, including teaching ability, work motivation, and supervision of the principal [16].

According to Article 1 paragraph (1) of Law i 14 of 2005 concerning Teachers and Lecturers, it states that "teachers are professional educators with the main task of educating, teaching, guiding, directing, training, assessing, and evaluating students in early childhood education through the education pathway. formal, basic education, and secondary education. Thus the indicators of teacher performance are: Educating, Guiding, Training, Evaluating..

\subsection{Principal Leadership}

Leadership is a translation of the word leadershif which comes from the word leader. Leader is a person who leads while the leader is his position. According to Agustinus Hermino that leadership is a trait possessed by a person who, because of the task he carries out, tries to influence his followers by obeying what is the instruction of the person who leads him [17]. According to Larry Bossidy (in Du Brin) the leadership of the principal is at the same time as a manager in the school because a leader also carries out management functions in charge of planning, organizing, controlling, and leading [18].

According to Wahjosumidjo, principal leadership is the principal's ability to mobilize, direct, guide, protect, exemplify, provide encouragement, and provide assistance to human resources in a school so that they can be maximally utilized to achieve goals that have been set [19]. The roles of school principals according to Aedi include: Principal as educator, Principal as manager, Principal as administrator, Principal as supervisor, Principal as leader, Principal as innovator, Principal as motivator, Principal as officials, the principal as an entrepreneur [20].

According to Mulyasa, principal leadership is: The principal's ability to influence, encourage, guide, and mobilize educational personnel and available resources, so that they run according to what was planned and work together in an atmosphere of high morality [21]. full of enthusiasm and awareness, in accordance with the existing regulations to achieve the goals that have been set together. Thus the indicators of principal leadership are: the principal as an educator, the principal as a manager, the principal as a supervisor, the principal as a motivator.

\subsection{Research Hypothesis}

Based on the theoretical basis and conceptual framework that has been described, the researcher can compile the research hypothesis as follows:

a) It is suspected that school culture, teacher performance, and principal leadership simultaneously have a significant effect on the quality of education at high schools in Ende District.

b) It is suspected that school culture, teacher performance, and principal leadership partially have a significant effect on the quality of education at senior high schools in Ende District.

c) It is suspected that teacher performance has a dominant effect on the quality of education at senior high schools in Ende Regency.

\section{RESEARCH METHODOLOGY}

This type of research uses quantitative analysis with the method used is quantitative description. The number of samples in this study were 72 respondents with the sampling method, namely purposive sampling. The data analysis technique used multiple linear regression analysis. 
International Journal of Advances in Scientific Research and Engineering (ijasre), Vol 6 (8), August -2020

\section{RESULTS AND DISCUSSION}

\subsection{Characteristics of Respondents}

The following can be presented a table regarding the characteristics of respondents at high school in Ende district as follows:

Table 1 Characteristics of Respondents

\begin{tabular}{|c|c|c|}
\hline \multicolumn{3}{|c|}{ Characteristics of Respondents at Syuradikara High School } \\
\hline Age Range & Frequency & Percentage \\
\hline$<30$ years & 7 & $29.16 \%$ \\
\hline $30-40$ years & 9 & $37.5 \%$ \\
\hline$>40$ years & 8 & $33.33 \%$ \\
\hline Total & 24 & $100 \%$ \\
\hline Gender & Frequency & Percentage \\
\hline Men & 14 & $58.3 \%$ \\
\hline Woman & 10 & $41.66 \%$ \\
\hline Total & 24 & $100 \%$ \\
\hline Level of education & Frequency & Percentage \\
\hline D3 & 3 & $12.5 \%$ \\
\hline S1 & 15 & $62.5 \%$ \\
\hline $\mathrm{S} 2$ & 6 & $25 \%$ \\
\hline Total & 24 & $100 \%$ \\
\hline Years of service & Frequency & Percentage \\
\hline$>10$ years & 5 & $20.83 \%$ \\
\hline$<25$ years & 10 & $41.66 \%$ \\
\hline 10-15 years & 9 & $37.5 \%$ \\
\hline Total & 24 & $100 \%$ \\
\hline \multicolumn{3}{|c|}{ Characteristics of Respondents at SMAK Frateran Ndao } \\
\hline Age Range & Frequency & Percentage \\
\hline$<30$ years & 9 & $37.5 \%$ \\
\hline $30-40$ years & 8 & $33.3 \%$ \\
\hline$>40$ years & 7 & $29.16 \%$ \\
\hline Total & 24 & $100 \%$ \\
\hline Gender & Frequency & Percentage \\
\hline Men & 13 & $54.16 \%$ \\
\hline Woman & 11 & $45.83 \%$ \\
\hline total & 24 & $100 \%$ \\
\hline Level of education & Frequency & Percentage \\
\hline D3 & 3 & $12.5 \%$ \\
\hline $\mathrm{S} 1$ & 16 & $66.66 \%$ \\
\hline $\mathrm{S} 2$ & 5 & $20.83 \%$ \\
\hline Total & 24 & $100 \%$ \\
\hline Years of service & Frequency & Percentage \\
\hline$>10$ years & 5 & $20.83 \%$ \\
\hline 10-15 years & 8 & $33.33 \%$ \\
\hline$<25$ years & 11 & $45.83 \%$ \\
\hline Total & 24 & $100 \%$ \\
\hline \multicolumn{3}{|c|}{ Characteristics of Respondents at SMAN 2 Ende } \\
\hline Age Range & Frequency & Percentage \\
\hline$<30$ years & 9 & $37.5 \%$ \\
\hline $30-40$ years & 8 & $33.3 \%$ \\
\hline$>40$ years & 7 & $29.16 \%$ \\
\hline Total & 24 & $100 \%$ \\
\hline Gender & Frequency & Percentage \\
\hline Men & 13 & $54.16 \%$ \\
\hline Woman & 11 & $45.83 \%$ \\
\hline
\end{tabular}


International Journal of Advances in Scientific Research and Engineering (ijasre), Vol 6 (8), August -2020

\begin{tabular}{|c|c|c|}
\hline Total & 24 & $100 \%$ \\
\hline Level of education & Frequency & Percentage \\
\hline D3 & 2 & $8.33 \%$ \\
\hline S1 & 17 & $70.83 \%$ \\
\hline S2 & 5 & $20.83 \%$ \\
\hline Total & 24 & $100 \%$ \\
\hline Years of service & Frequency & Percentage \\
\hline$>10$ years & 8 & $33.33 \%$ \\
\hline $10-15$ years & 7 & $29.16 \%$ \\
\hline$<25$ years & 9 & $37.5 \%$ \\
\hline Total & 24 & $100 \%$ \\
\hline
\end{tabular}

Source: Questionnaire Distribution, 2020

\subsection{Multiple Linear Regression Analysis}

To see the influence of School Culture, Teacher Performance, Principal Leadership on Quality of Education at High Schools in Ende District, testing was carried out using the SPSS Version 25.0 programming application which is shown in the following table:

Table 2 Results of Multiple Linear Regression Calculation the effect of School Culture, Teacher Performance, Principal Leadership on Education Quality

\begin{tabular}{|c|c|c|c|c|}
\hline Variable & Regression coefficient & Don't count & Sig. & Information \\
\hline School Culture & .037 & .236 & .814 & Not significant \\
\hline Teacher Performance & .367 & 3,614 & .001 & Significant \\
\hline Principal Leadership & .292 & 2,978 & .004 & Significant \\
\hline Constant & \multirow{7}{*}{$\begin{array}{l}5,728 \\
0.446 \\
0.421 \\
0.668 \\
18,238 \\
0,000 \\
72\end{array}$} & & & \\
\hline R Square & & & & \\
\hline Adjusted R square & & & & \\
\hline $\mathrm{R}$ & & & & \\
\hline F count & & & & \\
\hline Sig. F & & & & \\
\hline $\mathrm{N}$ & & & & \\
\hline \multicolumn{5}{|c|}{ The dependent variable = quality of education $(\mathrm{Y})$} \\
\hline F table $=$ & 2.74 & & & \\
\hline $\mathrm{T}$ table $=$ & 1,99547 & & & \\
\hline
\end{tabular}

Based on the table, it is known that the number is 0.668 , where there is a strong relationship between the influence of School Culture, Teacher Performance, and Principal Leadership on the Quality of Education in Senior High Schools in Ende Regency. Based on the table seen above, it can be seen that the value of the multiple linear regression constant is 5,728 and the coefficient value of the School Culture Variable is 0.037 , the value of the Teacher Performance coefficient is 0,367 , the value of the Principal Leadership regression coefficient is 0,292. So it can be connected with the Multiple Linear equation.

$\mathrm{Y}=\mathrm{a}+\mathrm{b} 1 \mathrm{X} 1+\mathrm{b} 2 \mathrm{X} 2+\mathrm{b} 3 \mathrm{X} 3+$ ei can be in the form of multiple linear equations, namely:

$\mathrm{Y}=5,278+0.037 \times 1+0.367 \times 2+0.292 \times 3+$ ei

Information :

$\mathrm{Y}=$ Quality of Education

$\mathrm{X} 1=$ School Culture

$\mathrm{X} 2$ = Teacher performance

X3 = Principal Leadership

ei $=$ Residual Error

The meaning of the Multiple Linear Equation above shows that:

a) The constant 5,278 means that if there are no school culture variables, teacher performance, school principal leadership where the variables $\mathrm{X} 1, \mathrm{X} 2, \mathrm{X} 3=0$, then the Quality of Education variable lies at a value of 5,278.

b) The X1 Regression Coefficient (School Culture) is 0.037 and it is negative, meaning that if there are no school culture variables, the quality of education will decline by $37.0 \%$. 
c) The regression coefficient X2 (Teacher Performance) is 0.367 and is positive, meaning that with the teacher performance variable, the quality of education will increase by $36.7 \%$.

d) The regression coefficient X3 (Principal Leadership) is 0.292 and is positive which means that with the Principal Leadership variable, the quality of education will increase by $29.2 \%$.

e) The coefficient of determination is 0.421

It has an implication that the variable School Culture, Teacher Performance, Principal Leadership is $42.1 \%$ and the remaining $57.9 \%$ is in the contribution of other variables that are not measured in this study.

\subsection{Hypothesis testing}

4.3.1 Hypothesis I

Table 3 F-Test Results for School Culture Variables, Teacher Performance, Principal Leadership

ANOVAb

\begin{tabular}{|l|c|c|c|c|c|}
\hline \multicolumn{1}{|c|}{ Model } & Sum of Squares & df & Mean Square & F & Sig \\
\hline 1 Regression & 961.860 & 3 & 320.620 & 18.238 & $.000 \mathrm{a}$ \\
Residual & 1195.418 & 68 & 17.580 & & \\
Total & 2157.278 & 71 & & & \\
& & & & & \\
\hline
\end{tabular}

Source: Primary Data Processed, 2020

a. Predictors (constant), LEADERSHIP OF SCHOOL, TEACHER PERFORMANCE, SCHOOL CULTURE

b. Dependent Variable: QUALITY OF EDUCATION

By using the $\mathrm{F}$ test, testing the first hypothesis says that the influence of school culture, teacher performance, and principal leadership simultaneously has a significant effect on education quality. Based on the results of multiple regression analysis, it is known that $\mathrm{F}$ count $=18.238$ and the probability is 0.000 because the probability value is <of $\alpha$ 0.05 , thus hypothesis I can be accepted.

\subsubsection{Hypothesis II}

Table 4 Partial Regression Coefficient Test

\begin{tabular}{|l|c|c|c|c|}
\hline \multicolumn{1}{|c|}{ Variable } & t count & t table & Sig. & Information \\
\hline School Culture & .236 & 1.99547 & .814 & Not significant \\
\hline Teacher Performance & 3.614 & 1.99547 & .001 & Significant \\
\hline Principal leadership & 2.978 & 1.99547 & .004 & Significant \\
\hline
\end{tabular}

Primary data sources were processed in 2020.

a) Variable of School Culture (X1) on Quality of Education (Y)

From the calculation of regression analysis, the value of $\mathrm{t}$ count $=.236$ while the value of $\mathrm{t}$ table $=1.99547$ so that $\mathrm{t}$ count $<\mathrm{t}$ table or a significance value of $0.814>0.05$, then $\mathrm{Ha}$ is boxed and $\mathrm{H} 0$ is accepted. This means that the School Culture variable (X1) does not have a significant effect on the Quality of Education. (Y)

b) Teacher Performance Variable (X2) on Education Quality (Y)

From the calculation of regression analysis, the value of $\mathrm{t}$ count $=3.614$ while the value of $\mathrm{t}$ table $=1.99547$ so that $\mathrm{t}$ count $>t$ table or a significance value of $0.001<0.05$ then $\mathrm{Ha}$ is accepted and $\mathrm{H} 0$ is rejected, meaning that the teacher performance variable (X2) has a significant effect on quality. Education. (Y)

c) Principal Leadership Variable (X3) on Education Quality (Y)

From the calculation of the regression analysis, the value of $\mathrm{t}$ count $=2.978$ while the value of $\mathrm{t}$ table $=1.99547$ so that $t$ count $>t$ table or a significance value of $0.004<0.05$ then Ha is accepted and $\mathrm{H} 0$ is rejected.This means that the Principal Leadership variable (X3) has a significant effect on Quality of Education (Y)

\subsubsection{Hypothesis III}

Table 5 Results of the Regression Coefficient Test for the dominant variables

\begin{tabular}{|l|c|c|c|c|c|c|}
\hline \multicolumn{1}{|c|}{ Variable } & $\mathbf{b}$ & $\mathbf{t}$ count & $\mathbf{t}$ table & sig & $\dot{\alpha}$ & Information \\
\hline School Culture & .037 & .236 & 1.99547 & .814 & 0.05 & Not significant \\
\hline Teacher Performance & .367 & 3.614 & 1.99547 & .001 & 0.05 & Significant \\
\hline Principal Leadership & .292 & 2.978 & 1.99547 & .004 & 0.05 & Significant \\
\hline
\end{tabular}

Source: primary data processed in 2020 
From the calculations in the table above, the coefficient value of each variable is School Culture (X1) 0.037, Teacher Performance (X2) 0.367 and Principal Leadership (X3) 0.292. which has a significant effect on the quality of education, namely teacher performance and principal leadership. If viewed from the coefficient value of the highest variable, namely teacher performance, it can be concluded that the variable that has the dominant influence lies in the teacher performance variable with a coefficient value of 0.367 . So thus the third hypothesis states that it is suspected that the teacher performance variable has a dominant effect on the quality of education at high schools in Ende Regency which is statistically proven with $\alpha=5 \%$.

\subsection{Discussion}

These results and discussions are directed at providing a comparison between the results of research analysis with relevant or not relevant theory and previous research, in addition to research on the influence of School Culture, Teacher Performance, Principal Leadership on Education Quality. At High School in Ende Regency.

\section{a. Simultaneous Influence}

1. The Influence of School Culture, Teacher Performance, Principal Leadership on Quality of Education in Senior High Schools in Ende Regency.

Based on the results of the above analysis, it shows that School Culture, Teacher Performance, and Principal Leadership simultaneously affect the Quality of Education in Senior High Schools in Ende District, with a significance value of $0.00<0.05$. This is in line withIn line with Sallis research which states that education quality is a function of an effective learning process, leadership, teacher participation, student participation, management, organization, physical environment and resources, school customer satisfaction, input and facilities support, and culture school [22]. The optimization of each of these components determines the quality of the school as an education delivery unit.

This is in the relevant research from Zubaida, "The influence of school culture and teacher work motivation on the quality of education at SMK N 1 PABELAN which says that the positive influence of school culture and teacher work motivation on the quality of education, based on the results of this study, it is known that culture schools have a positive relationship to the quality of education [23]. The study resulted in school culture variables that were not significant to the quality of education in several high schools in Ende district because some schools did not follow the values and it meant that the educators there sometimes did not obey the existing rules such as tardiness. come to school. This, according to his opinion, Zamroni provides a limitation that School Culture is a pattern of values, principles, traditions and habits that are formed in the long course of school, school culture is developed over a long period of time and becomes a reference and is believed by all school members so as to encourage positive attitudes and behavior of school residents[10]. The performance of a teacher at a school institution can have a positive impact on the development of the quality of education in schools.

According to Herdi that teacher performance is the result of achievement by teachers after carrying out their duties as teaching staff, which is supported by their performance in carrying out their duties in the field properly in procuring tools or human resources that show the charismatic nature of the teacher as a teacher and educator [14]. The achievement or good performance of an educator in schools can contribute to the quality of education in schools. In the results of this study, the performance of a teacher can have a significant effect where the school has a very good performance and needs to be appreciated in the progress of the quality of education in the school. The quality of education is also influenced by teacher performance. According to Prawirosentono in Usman performance or performance is an effort made from the work that can be achieved by a person or group of people in an organization in accordance with their respective authorities and responsibilities in order to achieve the goals of the organization concerned legally, does not violate the law and is appropriate with morals and ethics [24]. So it can be concluded that the performance of an educator is an achievement or an achievementwhich is supported by the performance in carrying out their duties in the field properly in the provision of tools or human resources that are owned which shows the charismatic nature of the teacher as a teacher and educator.The role of the principal greatly affects the performance of an educator, meaning that the principal can provide direction that can be followed and can be accepted by his subordinates, in this case a teacher. Teachers can follow directions from the principal well in supporting the quality of education in schools. An important factor that influences the improvement of the quality of education, one of which is the leadership of the principal, according to Daryanto, stating leadership is the process of influencing the activities of a group in the organization, leading to the achievement of goals, the success, and failure of the leader are determined by the nature and style of leadership in directing the dynamics of the group [25]. To influence other people a leader must have the maturity, intelligence, high self-confidence, consistency, assertiveness, willingness to supervise, partnerships, and others.

From some of the explanations for the variables above that are obtained and it can be concluded that the influence of school culture, teacher performance, leadership in the school heads together has a significant influence on the quality of education in senior high schools in Ende district. In the sense that the quality of education is influenced by several factors, educational outcomes are a function of the education system. And the quality of the school is a function of an effective learning process, the role of the principal's leadership, the participation of teachers, the participation of students, the participation of school organization management both the physical environment and resources and school customer satisfaction and is supported by input and facilities 
and school culture there is a high school in Ende District. And from the test results of the coefficient of determination, the influence given by School Culture, Teacher Performance, Principal Leadership is $42.1 \%$, and the remaining $57.9 \%$ is influenced by other variables such as work motivation, school climate, work discipline, and others. so that in this study it is not the main benchmark.

\section{b. Partial Influence}

1. The influence of school culture variables on the quality of education

In this study it is known that school culture does not have a significant effect on the quality of education at senior high schools in Ende district with a significant value of $0.814>0.05$. This is confirmed by the results of interviewsthat any increase in school culture which includes applied values is not obeyed by the school community, it will have an impact on decreasing the quality of education in schools. It is necessary to re-evaluate with all residents and school elements so that in the future, the school cultural values that have been applied can be carried out properly so as to improve the quality of education. In research Zubaida) states that there is an influence of school culture on the quality of education [23]. The results of Zubaida study are not in line with the results of this study because in this study there was no influence between school culture on the quality of education [23].

\section{The influence of teacher performance variables on the quality of education}

In the Teacher Performance Variable, there is a significant influence on the Quality of Education in high schools in Ende Regency, with a significant value of $0.001<0.05$, meaning that the role of teachers is very important and is the spearhead in the world of education. In addition, this research is also strengthened by the results of interviews that teacher performance is an important aspect of senior secondary schools in Ende Regency in carrying out their duties as teachers and educators as a whole so that the quality of education in senior high schools in Ende Regency can improve well. In line with Prawirosentono's research in Usman the quality of education is also influenced by teacher performance [24]. performance or performance is an effort made from the results of work obtained by a person or group of people in an organization in accordance with their respective authorities and responsibilities in order to achieve the goals of the organization concerned legally, does not violate the law and is in accordance with morals or ethics. Meanwhile, according to Whitmore (2014) simply states, performance is the implementation of the functions that are required of a person [26].

\section{The influence of principal leadership on the quality of education}

In the Principal Leadership Variable, there is a significant influence on the Quality of Education in senior secondary schools in Ende Regency, with a significant value of $0.004<0.05$, meaning that the leadership role of the principal is very good in carrying out his duties as a leader in the school. In addition, this research is also strengthened by the results of interviews that at high schools in Ende Regency, the leadership of the principal has really carried out its role and function as an educator, manager, administrator, supervisor, leader, innovator, and motivator, in order to achieve quality. good education in senior high schools in Ende district. In line with research Daryanto, The quality of education is also influenced by Principal leadership, leadership is the process of influencing the activities of an organized group, leading to the achievement of goals, the success and failure of the leader is determined by the nature and style of leadership in directing the dynamics of the group [25]. To influence others, a leader must have maturity (maturity), intelligence, high self-confidence, consistency, assertiveness, a willingness to supervise, partnerships and others.In line with Mulyasa research, the principal's leadership is one of the factors that can encourage schools to realize the vision, mission, goals and objectives of their school through planned and gradual programs [27].

\section{Teacher performance has a dominant influence on education quality}

In the third hypothesis, the teacher performance variable has a dominant effect on education quality with multiple linear regression coefficient values of 0.367 and t count 3.614, where teachers at high schools in Ende Regency already have a maximum role in showing fairly good work results, with assignments. primarily as an educator and teacher. This is in line with Wirawan research which states that to get an accurate performance appraisal, the assessment should not be carried out by the principal alone but also involves teachers as peers and supervisors or supervisors [28].

\subsection{Implications of Research Results}

In an educational institution it has two types of implications. Namely the theoretical implications and practical implications. The theoretical implication is the contribution of theories related to School Culture, Teacher Performance, Principal Leadership, while the practical implication is a contribution related to the Quality of Education in Senior High Schools in Ende Regency.

\section{1) Theoretical Implications}

In line with Sudrajad s opinion, quality education is education that is able to produce graduates who have the ability or potential, both academic and vocational potential, which are based on personal and social potential, as well as noble moral values, which are all life skills (life skill, Sudradjat continued, said that quality education is education that is capable of producing complete human beings (complete human beings) or humans with integrated personities, namely those who are able 
to integrate faith, knowledge, and charity [9]. The quality of education is influenced by several factors. Educational outcomes are a production function of the education system. The quality of education is a function of an effective learning process, the leadership role of the principal, the role of teachers, students, management, organization, physical environment and school customer satisfaction resources, input support and facilities, and school culture. The optimization of each of these components determines the quality of education as an educational delivery unit.

2) Practical Implications

Teacher performance, principal leadership has a significant effect on the quality of education. In this study, it was statistically tested that the teacher performance variable had a significant value of $0.001<0.05$ and $0.004<0.05$, which means that respondents at high schools in Ende Regency had the opinion that Teacher Performance and Principal Leadership were the top priority in improve the Quality of Education, and also in this study School Culture does not have a significant effect on the Quality of Education at high schools in Ende Regency with a significant value of $0.814>0.05$, meaning that respondents at high schools in Ende Regency have the opinion that School Culture is less prioritized in improve the Quality of Education, For this reason, senior secondary schools in Ende District need to re-evaluate with all residents and school elements so that in the future, the school cultural values that have been implemented can be carried out properly to improve the quality of education. In the third hypothesis, the teacher performance variable has a dominant effect on the quality of education in high schools in Ende Regency, with a multiple linear regression coefficient of 0.367 and t count of 3.614. This is in line with Wirawan's research which states that to get an accurate performance appraisal, the assessment should not be carried out by the principal alone but also involves teachers as peers and supervisors or supervisors [2].

The results of this study are expected to be able to become material for correction and evaluation by the parties and all elements, both school principals, teachers at high schools in Ende Regency. In addition, school principals and teachers can review or re-examine aspects of school culture which are important points in improving the quality of education, by applying values which are the essence of the school culture itself. The values contained in this have an important role in shaping the character of members of the organization at high schools in Ende Regency which are also the drivers for improving the quality of education.

\section{CONCLUSIONS AND RECOMMENDATIONS}

\subsection{Conclusion}

There are several findings in the study based on the results of the analysis, namely as follows:

1) In the independent variables, namely School Culture, Teacher Performance, Principal Leadership, simultaneously influence the Quality of Education at High Schools in Ende Regency, which means that the higher the School Culture, Teacher Performance and Principal Leadership, the higher the Quality of Education.

2) The school culture variable (X1) does not have a significant effect on the quality of education at high schools in Ende Regency. With the results of the interviews, it was found that the school educational institutions had applied the rules and values of the school culture but were not carried out properly by each school member. so that in this study partially school culture did not have a significant effect on the quality of education at senior high schools in Ende district.

3) The teacher performance variable has a dominant influence on the quality of education. The performance of a teacher as a teacher in the world of education is very important in improving the quality of education. With the good performance results of a teacher at a school educational institution, it can certainly have a good impact on improving the quality of education in schools

\subsection{Suggestion}

\section{1) The teachers}

In the world of teacher education is the spearhead for educating the nation's children with the main task of educating, guiding, directing, training and must be able to have academic abilities in accordance with their fields and competencies. So that performance can be improved so that the teaching and learning process goes well. With the good work that has been shown by teachers at high schools in Ende District, it is necessary to continue to improve in the future and continue to stand on the values contained in the culture of school organizations and become guidelines and norms for all members of the organization.

2) Educational institutions

a) School culture

It is hoped that high school education institutions in Ende Regency will be more serious in overcoming the values and rules of school culture that have been implemented by school institutions so that in the future it is even better.

b) For Teachers

In the teaching and learning process, teachers in high schools in Ende should be improved in carrying out more professional duties so that the performance of teachers with the main role of teachers as educating, guiding, directing, 
training for the future can provide better quality education. And continue to stand on the values contained in the culture of the school organization and become the guidelines and norms for all members of the organization.

c) For the leadership of the principal

In high school in Ende District, the principal has done his job well in carrying out his role and function as a leader with the main task of being an educator, manager, supervisor, and motivator. In contributing to improving the quality of education in schools. And continue to stand on the values contained in the culture of the school organization and become the guidelines and norms for all members of the organization.

\section{3) Next Researcher}

For further researchers, it is hoped that they can add research objects. So that it can make comparisons with other schools, along with other variables such as: Teacher Motivation, Education Level and others. Because this study has several variables and only a few schools were selected.

\section{REFERENCES}

1. UU. RI. No. 20 Tahun 2003. Sistem Pendidikan Nasional. Jakarta: Asokadikta dan Durat Bahagia.

2. Madjid, Abdul, 2016. Pengembangan Kinerja Guru Melalui: Kompetensi, Komitmen dan Motivasi Kerja. Yogyakarta: PT. Samudra Biru.

3. Cepi Triatna 2015. Pengembangan Manajemen Sekolah. PT Remaja Rosdakarya. Bandung.

4. Sukmadinata. 2006. Metode Penelitian Pendidikan, Remaja Rosdakarya, Bandung

5. Suharsaputra. 2010. Administrasi Pendidikan. Bandung: PT. Rafika Aditama.

6. Rosyada, Dede. 2013. Paradigma Pendidikan Demokratis, Sebuah Model pelibatan Masyarakat dalam Pendidikan. Jakarta: Prenada Media.

7. Depdiknas, 2001. Kamus Besar Bahasa Indonesia. Jakarta ;Balai Pustaka.

8. Usman, Husaini. 2006. Manajemen, Teori, Praktik, dan Riset Pendidikan. Jakarta:Bumi Aksara.

9. Sudrajat, Akhmad. 2005. Kompetensi Guru Dan Peran Kepala Sekolah (http://www.depdiknas.go.id/inlink).

10. Zamroni. 2011. Pendidikan Demokrasi pada Masyarakat Multikultural. Yogyakarta: Gavin Kalam Utama.

11. Wahjosumidjo. 2007. Kepemimpinan Kepala Sekolah, Tinjauan Teoritik dan Permsasalahannya, Jakarta: PT. Raja Grafindo Persada.

12. Moerdiyono. 2010. Artikel Budaya Sekolah, http://staff.uny.ac.id. Diakses tanggal 30/ 12/2012.

13. Robbins, P. Stephen. 2003. Perilaku Organisasi. Edisi Sembilan, Jilid 2. Edisi Bahasa Indonesia. PT Indeks Kelompok Gramedia, Jakarta.

14. Herdi, 2010. Bimbingan dan Konseling Kesehatan Mental di Sekolah, Bandung : Remaja Rosdakarya.

15. Samsudin, Sadili. 2006. Manajemen Sumber Daya. Bandung : Pustaka Setia.

16. Yuliani, T. (2015). Faktor-Faktor Yang Mempengaruhi Kinerja Guru SMA Negeri Di Balikpapan. Jurnal Akuntansi, $270-280$.

17. Hermino, Agustinus. 2014. Manajemen Kurikulum Berbasis Karakter, Bandung: Alfabeta.

18. Du Brin, Andrew J. 2006. Leadership (Terjemahan). Edisi Ketiga. Prenada Media: Jakarta

19. Wahjosumidjo. 2005. Kepemimpinan Kepala Sekolah Tinjauan Teoritik dan Permasalahannya. Jakarta: Rajawali Press.

20. Aedi, 2016. Manajemen Pendidikan \& Tenaga pendidikan. Gosyen Publishing Jatirejo 58B RT07/RW21 Sendangadi, Mlati, Sleman, Yogyakarta, 55285.

21. Mulyasa, E. 2009. Menjadi Kepala Sekolah Profesional. Bandung: Remaja Rosda Karya.

22. Sallis, Edward. 2010. Total Quality Management in Education, Manajemen Mutu Pendidikan. Cetakan ke.XI. Jogjakarta: IRCiSoD.

23. Zubaidah, Siti. 2015. Pengaruh budaya sekolah dan motivasi kerja guru terhadap mutu pendidikan di SMK N 1 Pabelan. Seminar Nasional Ilmu Pendidikan UNS 2015. Sebelas Maret University.

24. Usman, M U. 2009. Menjadi Guru Profesional.Bandung : PT. Ramaja Rosdakarya.

25. Daryanto. 2011. Media Pembelajaran. Bandung:Sarana Tutorial Nurani Sejahtera. 
International Journal of Advances in Scientific Research and Engineering (ijasre), Vol 6 (8), August -2020

26. Whitmore, John. 2014. Coaching For Performance.

27. Mulyasa. 2014. Pengembangan dan Implementasi Kurikulum 2013. Bandung: Remaja Rosdakarya.

28. Wirawan. 2012. Evaluasi Teori, Model, Standar, Aplikasi dan Profesi. Jakarta: Rajawali Pers. 